\title{
THE APPLICATION OF WAHDAH METHOD IN MEMORIZING THE QUR'AN FOR STUDENTS OF SMPN 1 UNGGUL SUKAMAKMUR
}

\author{
${ }^{1 *}$ Wahyu Khafidah, ${ }^{2}$ Wildanizar, ${ }^{3}$ Tabrani, 4 Nurhayati, 5 Zubeir Raden \\ ${ }^{12345}$ Universitas Serambi Mekkah, Aceh \\ ${ }^{1 *}$ wahyukhafidah@serambimekkah.ac.id
}

\section{ARTICLE INFO}

Article history

Received 2/1/2020

Revised 23/3/2020

Accepted 12/5/2020

Keywords

Al-Qur'an Application Memorizing Al-Qur'an Memorization Method Memory

\begin{abstract}
This study aims to show that memorizing of Qur'an using the Wahdah method has satisfactory results in Aceh Besar. This study uses a quantitative method. The population in this study was 400 students at SMPN 1 Unggul Sukamakmur, while the number of teachers teaching Islamic education subjects was five people. Because the population is too large, the object of research is five Islamic education teachers, 40 students, and the principal of SMPN 1 Unggul Sukamakmur. Based on the results of interviews with Islamic education teachers, we conclude that they have become familiar with and mastered the "Application of the Wahdah method." However, the teachers have not fully applied all Wahdah theories. Therefore, further research is expected to be carried out for further action. This is an open access article under the CC-BY-SA license.
\end{abstract}

\section{INTRODUCTION}

The Qur'an is the word of God that has no evil in it, and the Qur'an is the most significant and eternal miracle for the Prophet. (Q.S. Al-Hijr: 9) (Nawabudin, 1991). Al-Qur'an is original and pure, following what was taught by the Prophet Muhammad to his companions. Allah was the one who guarded. Allah's preservation of the Qur'an does not mean that Allah directly safeguards the phases of the writing of the Koran, but Allah involves His servants to help protect the Qur'an (Sakho, 2000). The verse above attracts Muslims to memorize the Qur'an for the sake of the integrity of the Qur'an itself. Memorizing the Qur'an (Zuhurudeen, 2016 ) is the first step in a research process. Ahsin (2000) states that what Hafiz or Qur'an memorizers do in understanding the content of the Qur'anic sciences is surely after the necessary process of reading al-Qur'an. In contrast, Al-Lahim (2008) mentions that there are Qur'an learners who do the opposite. They learn the contents of the Qur'an first then memorize it. 
An educational program to memorize al-Qur'an is a program to learn al-Qur'an with mutqin (intense memorization) of lafadz al-Qur'an and their meanings actively, which makes it easy to present them when faced with various problems of life (Aqel \& Zaitoun, 2015). As the Qur'an always exists and lives in the heart all the time, it becomes to apply and practice (Suud, 2017). Memorizing the Qur'an is not a piece of cake. There are complexities involved in the accuracy of reading and pronunciation because a slight mistake is a sin. If left unchecked and not strictly protected, then the purity of the Qur'an will not be maintained in every aspect (Rauf, 2004).

Memorizing the Qur'an is not an easy, simple task, and not everyone can do it without taking particular time and seriousness because memorizing the Qur'an is a grand task (M. Suud, 2017). It is not an exaggeration to say that learning the Qur'an is exhausting because there are many problems faced by the Hafiz to reach a high degree in the sight of Allah. Ahsin (2000) adds that interest in learning Qur'an starts from the development of interest, the creation of the environment, the distribution of time to the method of memorization itself.

Many Hafizs also complain that memorization is challenging due to distractions, both psychiatric and environmental disorders. Each of the Muslims, of course, aspires to memorize the Qur'an (Al-Attas, 2011). Everyone also feels the spirit that they can learn it consistently, memorizing letter by letter, juz by juz (Syachrul, Wise, \& Huda, 2019). After that, there begins a variety of whispers and inner disturbances to make the person lazy, and the spirit increasingly loosens because of many similar letters, confusing words, spare time, and a lot of busyness. Memorizing the Qur'an is different from memorizing a book or dictionary. Al-Qur'an is Kalamullah, which will elevate the level of those who learn it. Therefore, Hafiz needs to know the efforts so that the quality of memorization is maintained well (Al-Saggaf, Yasin, \& Abdullah, 2014). Allah Almighty will provide convenience to those who want to memorize it and provide help for them. The process of learning the Qur'an, according to Syaiful Romadhon, Rahmah, \& Wirani (2019), is more accessible than maintaining it. Many Hafizs complain because, at first, the memorization is good and smooth, but at one time, the recitation disappears from his memory (Sudirman, et. al., 2019). It's issue can occur because there is no maintenance.

Therefore, to improve memorization of the Qur'an must have the right ways, so that memorization of the Qur'an will get better. One accessible and general method to apply in schools is the Wahdah Method. It is the method of memorizing the Qur'an by learning one by one verse, then continuing in the following verses, and so on until reaching one page (El-Seedi et al., 2019). After seeing the background description above, the researcher tries to study the Wahdah recitation Method, with the title: "The Implementation of the Wahdah Method in Memorizing Al-Qur'an at SMPN 1 Unggul Sukamakmur". Moving on from the background above, the researcher sees problems that require resolution. For this reason, we makes a problem statement as follows: How is the Wahdah Method applied in memorizing Al-Qur'an students at SMPN 1 Unggul Sukamakmur? The purpose of this research 
and discussion is to find out how the application of the Wahdah Method in memorizing the Qur'an for students of SMPN 1 Unggul Sukamakmur.

\section{A. Definition of Wahdah Method}

The word 'method' comes from the Greek (Greece) Metha and Hades. Metha means through/passing, while Hades means the approach/way traversed to achieve specific goals. So, the method is through the approach/way achieved to reach a specific goal. Memorizing Al-Qur'an is a valuable treasure for sincere people. It is because al-Qur'an is the words of God which can be sharia for the readers later on the Judgment Day. Memorizing Al-Qur'an to obtain its virtues has a variety of different ways (Ahmad Syadali and Ahmad Rofi'i, 1997). The method is essential in achieving the success of memorization because it determines the success or failure of a goal, an integral part of the learning system. Furthermore, Peter R. Senn argues, "a method is a procedure or a way of knowing something, which has systematic steps." The teacher will more easily determine the most suitable method for situations and conditions that are specific to it if they understand the nature of each method. Winarno Surahmad (Surahmad, 2002) said that several factors influenced the selection and determination of methods.

These factors are students who are potential human beings. Talent or intelligence possessed, according to Gardner, is students that have multiple intelligences and diversity. The goal is the intended target of each teaching and learning activity. In this case, the method must obey the will of the purpose and not vice versa. Since it is the ability desired by the goal, the Wahdah method must fully support it. The situation of teaching and learning activities that the teacher creates is not always the same. On the other hand, a suitable method is following the existing situation. Therefore, the current condition affects the selection and determination of teaching methods. Facilities support students' learning activities at school.

Complete or not learning facilities then affect the choice of teaching methods. Every teacher has a different personality. Some teachers, for example, can be talkative or not. Therefore, the teacher's personality will determine the selection of the method used. The method used in this thesis research was the Wahdah method to memorize the Qur'an quickly. Learning methods not only function as a way to deliver the material because, in learning activities, teachers also have to manage the students to achieve goals appropriately. So, the learning method is a method used to implement plans that have been prepared in the form of real and practical activities to reach learning objectives (Nawabudin, 1988).

Guidelines are needed first from several factors, including the purpose, students, situations, facilities, and infrastructure, in determining effective methods, as well as the personality of a teacher. In this case, Sutari Imam Barnadib also states that four factors influence the selection of methods, namely 
the objective, educator, instrument factor, and the surrounding natural factors (Sutari Imam Barnadib, 1987). Wahdah method is to memorize one by one of the verses. The learners can read each verse ten times or twenty times or more so that this process can form a pattern of recitation. After the students can memorize thoroughly, then they may proceed to the next verses in the same way, and so on. If they have reached one page, then they can memorize the verses repeatedly until smooth. In testing the ability of the students, the supervising teacher is not too rigid, but there is no limit time for students to memorize. The ability test can be done in front of other students in a learning forum or privately, i.e., every student learns in front of the teacher.

Wahdah method has several advantages (Arifin, 1996), while the benefits are as follows: 1) It is easier to do for students, 2) Students' memories will get stronger, 3) Makhorijul Letters students in reciting the Qur'an are guaranteed, 4) The students' term in adding memorization is more secure, 5) It maintains tajweed and some rules of reading the Qur'an with tartil , 6) The memorization is faster because of memorized words, 7) Students more quickly absorb the learned material (Ibn Hajar al-Asqalany, 1993).

A good memorization strategy is necessary to help facilitate memorized verses, especially by using the Wahdah method. The strategies include the following: 1) Applying a double repetition strategy. To achieve the right level of memorization, it is not enough with one process. Thus, it takes repetition to memorize all verses. For example, if the learners have learned one verse in the morning and achieved a steady level of memorization, they should do it again in the afternoon, they can also repeat while praying. 2) Not moving on to the next verse before one verse is complete. 3) Learning the sequence of memorized verses, 4) Using one type of manuscript to avoid confusion of the memorization patterns, 5) Understanding the meaning of memorized verses, 6) Paying attention to similar verses because there are so many similar verses in the Qur'an, so memorization must be careful, 7) Reporting the recitation to the supervisor or teachers (Ahsin, 2000).

Types of Methods in Memorizing Al-Qur'an. There are; 1)) Tahfiz method is the process of repeating something rote, either by reading or listening, 2) The recitation method is reading the Qur'an, which is an activity and the will to read with a beautiful and good rhythm, 3) the Talaqqi method is a process of reporting or listening to memorization to the teacher, 4) The Tardid method is to repeat the recitation.

\section{B. The Teachers' Roles in Applying Wahdah Method}

The existence of teachers has existed for centuries. Since the beginning of the earliest humans, Prophet Adam was the teacher of all teachers, the teacher of the inventors, the teacher of the most pious creatures, namely Allah the Almighty. In the Qur'an, Allah explains that He taught Adam everything in the world. Then, the Prophet Adam taught it to Eve. The term teacher is currently 
experiencing shrinking the meaning of the teacher is a person who teaches at school. Even though teachers nowadays only teach students at school, their roles are still necessary. They help students to find out where to go and what to do in the world. Humans are weak creatures, who in their development, need the help of others, from birth to death. Parents enroll their children in school in the hope that the teachers can educate them to become humans who can develop optimally.

Teachers also must race in learning, by providing ease of learning for all student participants, especially in applying the Wahdah method in memorizing the Qur'an in SMP N 1 Unggul Sukamakmur, to develop their potential optimally. In this case, the teacher must be creative, professional, and fun (As-Shibuni, 282AD). The teachers may place themselves as: 1.) Parents who are full of love for their students; 2) Friends, a place to complain and express feelings for students; 3) Facilitators, who are always ready to provide convenience and serve students according to their interests, 4) abilities, and talents, 5) contributors for parents to supervise the problems faced by students and provide solutions, 6) Drivers for students' self-confidence, courage (John E. Roberts, 2020), and responsibility, 7) Helpers for students to interact with others naturally, 8) A bridge to develop a cognitive socialization process between students, parents, and the environment., 9) Supervisors of students' creativity in memorizing the Koran, 10) Helpers when needed to learn the Qur'an.

Those are some of the roles that the teachers must undertake in optimizing the students' potential. At present, the problems affecting the education sector are diverse and classified as severe, starting from educational facilities and infrastructure, lack of competent teaching staff, causing education far from expectations. Poor school conditions and classrooms leak when it rains, and some school buildings collapse.

The best human beings for those who study the Qur'an (students) and those who teach (teachers) give birth to social institutions and at the same time cultural devices in the form of educational institutions, study groups, and various individual activities to teach the Qur'an (Zen, 1998). If paying attention to the life of the Muslim community, theological motives solely drive the growth of educational institutions, study groups, and various individual activities to study and teach the Qur'an. The theogenetic purpose is an awareness in a person to realize a life order based on his sense of responsibility to God.

The interaction among the teachers and students is a dynamic social interaction because of the psychological factors that influence each other (Suud \& Subandi, 2018). A teacher who wants to convey a message to a student in the form of the subject matter will face several challenges such as the ability to capture and process information, personal and social life background, level of desire or motivation, and so on (Gerungan, 1986). With the problems faced, teachers continue to strive so that they can teach material properly. From that situation, 
there comes various strategies, approaches, tactics, techniques, and methods in the teaching and learning process (H.A. Muhaimin Zen, 1998). Professional teachers' attitudes and behaviors can set an example for students, develop competencies, and the potential of students.

The roles of the teacher in improving the memorization of the Qur'an by using the Wahdah method (Qosim, 2008) are as follows: 1) determining the goals to achieve; 2) learning the material that will be taught by an educator; 3 ) using the method provided, that is the Wahdah method; 4) giving assignments to students in the form of memorization and repeating existing memorization; 5) Encouraging students to be more serious; 6) Always advising students; 7) Giving a lot of motivation for students to be more active in memorizing. Teaching students more optimally so that they are more serious. Educational experts in Western countries have conducted studies on the role of teachers.

The diverse roles of teachers have been identified and reviewed by Pullias and Young, Manan and Yelon, and Weinstein. The roles are as follows: Teacher as educator, the teacher is an educator, who becomes a figure, role model and identification for students, and their environment. Therefore, teachers must have specific quality standards, which include responsibility, authority, independence, and discipline.

Various factors, such as motivation, maturity, the relationship of students with teachers, verbal abilities, levels of freedom, security, and teachers' skills in communication, influence students' learning activities. If the above factors are met, then through learning, students can learn well. The teachers must be transparent to students and skilled in solving problems. The teacher as a guide, the teachers are a travel guide who, based on their knowledge and experience, is responsible for the smooth-running trip. In this case, the term 'travel' does not only involve physical but also deeper mental, emotional, creative, moral, and spiritual journeys.

As a travel guide, teachers need high competence to conduct the following four responsibilities: First, the teacher must plan objectives and identify the competencies. Second, the teachers must see the involvement of students in learning, and most importantly, students carry out the learning activities not only physically, but they must be involved psychologically. Third, teachers must interpret learning activities. Fourth, teachers must conduct an assessment or evaluation.

Teacher as a coach, the education and learning process requires skill training, both intellectual and motoric, thus requiring teachers to act as trainers (Nawabudin, 1991). This fact further lies in the 2004 competency-based curriculum because without training, teachers will not be able to demonstrate mastery of essential competencies and will not be proficient in a variety of skills developed following standard material. Teacher as an advisor, the teacher is an advisor to students as well as parents, although they do not have specialized 
training as an advisor and in some cases, cannot expect to advise students. The teacher as an innovator, the teacher translates past experiences into a meaningful life for students. In this case, there is a deep and broad gap between one generation and another, so the involvement of parents means more than our grandmother (Nawabudin, 1991). A student who is studying now, psychologically is far from human experience that must be understood, digested, and realized in education.

The teacher as a role model and example, the teacher is a role model or example for students and all those who consider him as a teacher. There is a high tendency to assume that this role is not natural to challenge or get rejected. As an example, of course, what the teacher does will be highlighted by students and those around him. There are several things to consider by the teacher, such as essential attitude, speaking style, work habits, attitude through experience and mistakes, dress style, human relations, thinking processes, neurotic behavior, taste, decisions, health, life style in general. Teacher as a person, the teacher must have a personality that reflects an educator. The phrase is that "teachers should be obeyed and imitated." Being obeyed means that the messages conveyed by the teacher can be trusted, and their lifestyle can be imitated or emulated.

There are several ways to motivate students to learn to memorize the Qur'an as follows: a) clarifying the objectives to the students. b) giving a gift so that they are more active in learning, c ) creating a good rival or competition, the teacher tries to hold a competition among students to improve student achievement and work to enhance previous performances further, d) generating encouragement to students to learn to memorize the Koran, the strategy is to give maximum attention, so students are more interested in learning to remember, e) giving constructive praise so students are more motivated to get even better achievements, f) forming good study habits, such as making a study schedule every day, g) customizing the subject matter with the experience and abilities of students.

\section{METHODS}

A method is an effort done by researchers in revealing data and looking for the truth of the problem under study, which is a matter of methods used in research. According to Winarno Surahman, "The way to search for truths that are considered scientific is through the method of inquiry" (Surahman, 1992). The use of the investigation method is to find valid, accurate, and significant data on the problem so that it can uncover the problem under study. According to Sutrisno Hadi (Hadi, 1990), "A research, especially in empirical science, generally aims to find, develop or test the truth of a knowledge." Research is a series of scientific activities in the context of solving a problem. The results of the study are never intended as a solution directly to the issues faced because research is only part of a more considerable problem-solving effort. The function of research is to find explanations 
and answers to problems and provide alternatives for possibilities used to solve analysis. The types of this research include field research (library) and library (library research). The aim is to intensively study the background, current status, and environmental interactions that occur in a social unit such as individuals, groups, institutions, or communities (Azwar, 2005).

This research uses a quantitative approach that starts from the data and ends at the conclusion, the target or object of the study is limited so that the data taken can be taken over as much as possible and so that this research is not likely the widening of the research object. Therefore, the credibility of the study determines the quality of the study. Every research requires data and information from reliable sources so that the data and information can answer research problems or test hypotheses. In this case, the researcher needs to determine in advance the population to obtain data or information required to solve the problems encountered in this study. According to Suharsimi Arikunto, the population is the total amount used as the object of research (1993), while the sample is a portion of the population considered to represent the whole (population).

As for the population in this study were all 400 students in SMPN 1 Unggul Sukamakmur, while the number of teachers of Islamic education was five people. Since the population was so large, the researcher intended to take a portion of the population as a research sample using the reference suggested by Suharsimi Arikunto, namely "if the subject is less than 100, it is better to take all so that the research is population research. Furthermore, if the subject is large, it can be taken between $10 \%-15 \%$, or $20 \%-25 \%$ ". Since the population is too large, the objects of the study were 5 Islamic teachers, 40 students ( $10 \%$ of the population), and the principal of SMPN 1 Unggul Sukamakmur.

Observation is a systematic observation and recording of symptoms that appear on the object of research. As for this study, the researcher conducted direct observation on SMPN 1 Unggul Sukamakmur. An interview is a process of conversation to construct about people, events, activities, organization, motivation, feelings, etc. conducted by two parties, namely the interviewer, who asks questions with the interviewed person (interviewee). In this case, the researcher conducted interviews with five Islamic Islamic Education teachers and the principal of SMPN 1 Unggul Sukamakmur.

A questionnaire is several written questions used to obtain information from the respondent in the sense of a report about his personality or issues he knows. As for this study, the researcher distributed questionnaires to 40 students of SMP N 1 Unggul Sukamakmur. The questionnaire distributed in this study was a closed questionnaire. Documentation is a method carried out by searching for data related to research variables in the form of notes, transcripts, books, newspapers, magazines, and so on. This step was to get information about the problem studied. In this study, the researcher also asked the administrative staff through the principal 
and the administration section regarding data relating to the number of students, teachers, curriculum, and others related to this study.

\section{RESULT AND DISCUSSION}

Data collection on the application of the Wahdah method in SMP N 1 Unggul Sukamakmur was by interviewing Islamic Education teachers and principal of SMPN 1 Unggul Sukamakmur, as well as distributing questionnaires to the students. The forms of questions that included multiple choice answers and would be an option for multiple choice. In this study, the researcher interviewed five Islamic Education teachers with different streams, namely: Quran Hadith, Aqeedah Akhlah, Fiqh, TBA, and Tahfiz. Based on the results of interviews with the teachers at SMPN 1 Unggul Sukamakmur, they have been familiar with applying the Wahdah Method. In other words, the teachers at SMPN 1 Excellent Sukamakmur have mastered the Wahdah method. However, they have not been able to apply the Wahdah method entirely. The first table below explains the implementation of the Wahdah method.

Table 1.

Do the students recognize the Wahdah method?

\begin{tabular}{|c|l|c|c|}
\hline No. & \multicolumn{1}{|c|}{ Alternative answers } & F & $\%$ \\
\hline a. & I Yes & 38 & $95 \%$ \\
b. & N No & - & - \\
c. & K Not sure & 2 & $5 \%$ \\
d. & T Not at all & - & - \\
\hline & Total & 40 & $100 \%$ \\
\hline
\end{tabular}

Source Data: Questionnaire

Based on the table above, the students have been familiar with the Wahdah method and practice it directly. The superior students of SMPN 1 have mastered the Wahdah method well seen from the results of research through the distribution of questionnaires to students. As many as 38 students or $95 \%$ answered that they knew the Wahdah method, and only 2 students or $5 \%$ responded that they did not. Thus, the result proves that students can get to know the Wahdah method well. Students memorizing al-Qurán with pleasure and happy (Bahiroh, S. et.al., 2019). Besides, students' mastery of the Wahdah method is visible by providing equal opportunities to all students without discriminating between students who are able and who are less able. More details are in the table below. 
Table 2 .

Besides the Wahdah method, what are other methods used to memorize Al-Qur'an?

\begin{tabular}{|l|l|c|c|}
\hline No. & \multicolumn{1}{|c|}{ Alternative answers } & F & $\%$ \\
\hline a. & Tahfiz Method (memorizing) & 36 & $90 \%$ \\
b. & Tilawah Method (adorning) & 4 & $10 \%$ \\
c. & Talaqqi Method (delivering) & - & - \\
d. & Tardid Method (repeating) & - & - \\
\hline \multicolumn{2}{|c|}{ Total } & 40 & $100 \%$ \\
\hline
\end{tabular}

Source Data: Questionnaire

Based on the above table, most students, namely 36 students or $90 \%$, said that besides the Wahdah method, the Tahfiz method was the second favorite method in memorizing the Qur'an. Another small part, as many as four students or $10 \%$, said that the recitation method was in third place. This result is also in line with SMPN 1 Unggul Sukamakmur's teacher's statement. He stated that the teachers did not use the tahfiz, the talaqqi, and the Tardid method often as they used the Wahdah method and the recitation method. The students felt those two methods more practical than the others (interview: P1). Then the group method, the discussion method, the lecture method, and the demonstration method are also used in memorizing the Quran because using these methods can make it easier for students to learn (interview: P2). The results of the subsequent questionnaire analysis about memorizing the Qur'an using the Wahdah method at SMPN 1 Unggul Sukamakmur in a week, are in the following table:

Table 3.

How many times a week do the students memorize using the Wahdah method?

\begin{tabular}{|c|l|c|c|}
\hline No. & \multicolumn{1}{|c|}{ Alternative answers } & F & $\%$ \\
\hline a. & Once & - & - \\
b. & Twice & - & - \\
c. & Three times & - & - \\
d. & Four times & 40 & $100 \%$ \\
\hline \multicolumn{2}{|c|}{ Total } & 40 & $100 \%$ \\
\hline
\end{tabular}

Source Data: Questionnaire

Based on the above table, it can be seen that all students or as many as 40 students or $100 \%$ stated that memorizing the Qur'an in a week amounted to four times using the Wahdah method in SMP N 1 Unggul Sukamakmur. Furthermore, the themes presented are Wahdah methods that have a significant influence on students to more describe clearly in the following table. 
Table 4.

In your opinion, has the application of the Wahdah method at SMPN 1 Unggul Sukamakmur given a significant impact to you in memorizing the Qur'an?

\begin{tabular}{|c|c|c|c|}
\hline No. & \multirow[t]{2}{*}{ Alternative answers } & $\mathrm{F}$ & $\%$ \\
\hline a. & & 33 & $82.5 \%$ \\
\hline b. & Enough & 1 & $2.5 \%$ \\
\hline c. & Not really & 5 & $12.5 \%$ \\
\hline d. & No & 1 & $2.5 \%$ \\
\hline & Total & 40 & $100 \%$ \\
\hline
\end{tabular}

Source Data: Questionnaire

Based on the description of the table above, the application of the Wahdah method in SMP N 1 Unggul Sukamakmur has given significant influence on the students, as proved by the highest percentage of 33 students or $82.5 \%$ answering yes. In contrast, others 1 or $2.5 \%$ answered enough, five students or $12.5 \%$ answered not really, and one student or $2.5 \%$ answered no. Based on the above table, most students, namely 25 students or $62.5 \%$, said that students often repeat their memorization at home, while as many as 15 students or $37.5 \%$ said they sometimes happen their recitation at home.

\section{CONCLUSION}

Based on the results of research and discussion, researchers try to draw some conclusions. With the Wahdah method, the results of memorizing students become satisfying. Memorizing the Qur'an with the Wahdah method is very fun for students. The presence of students proves that they are happy with the Wahdah method. Students who memorize the Qur'an with the Wahdah method have shown more memorized the Qur'an compared to other methods at SMPN 1 Sukamakmur. The students who attended tahfiz class by using Wahdah method also proved that many had taken the opportunity to attend the Qur'an recitation musabaqah in Banda Aceh. Therefore, As a researcher, the authors might have the limitations of the study, it can be provided with some suggestions for the next research. We offered to try using the Wahdah method for children of middle school age to memorize the Qur'an with this method. Future studies are expected to be carried out about the role of the teacher in increasing student enthusiasm in teaching the method of memorizing the Qur'an with the Wahdah method. This is due to the results of research showing that many teachers have not yet maximized the teacher's role in teaching this Wahdah method to students.

\section{REFERENCES}

Abdu al-Rabb Nawabudin. (1988). Metode Efektif Menghafal al-Qur'an. Jakarta: CV Tri Daya Inti.

Abdul Aziz Abdul Rauf. (2004). Kiat Sukses menjadi Hafidz Qur'an Da'iyah. Bandung: Syaamil Cipta Media. 
Abdurrab Nawabudin. (1991). Teknik Menghafal Al-Qur'an. Bandung: Sinar Baru. Ahmad Syadali dan Ahmad Rofi'i. (1997). Ulumul Qur'an. Bandung: PT Pustaka Setia.

Ahsin, W. (2000). Bimbingan Praktis Menghafal Al-Qur'an. Jakarta: Bumi Aksara.

Al-Attas, R. (2011). The Qur'an and memory a (study of the effect of religiosity and memorizing Qur'an as a factor on memory). Alzheimer's E Dementia, 7(4), S641. https:// doi.org/10.1016/j.jalz.2011.05.1838

Al-Lahim, K. bin A. K. (2008). Mengapa Saya Menghafal Al-Qur'an. Surakarta: Daar An-Naba.

Al-Saggaf, M. A., Yasin, M. S. M., \& Abdullah, I. H. (2014). Dualism of Soul-person in English Translated Texts of the Qur'an. Procedia - Social and Behavioral Sciences, 118, 42-50. https:// doi.org/10.1016/j.sbspro.2014.02.006

Amjad Qosim. (2008). Hafal al-Qur'an Dalam Sebulan. Solo: Amjad Qosim.

Aqel, M. J., \& Zaitoun, N. M. (2015). Tajweed: An Expert System for Holy Qur'an Recitation Proficiency. Procedia Computer Science, 65, 807-812. https:/ / doi.org/10.1016/j.procs.2015.09.029

Arifin, M. (1996). Ilmu Pendidikan Islam. Jakarta: Bumi Aksara.

Bahiroh, S., Pratiwi, S. A., \& Fitriah, M. S. (2019). Improving Student Happiness through the Snowball Throwing Method in the Implementation of Student Counselling Groups of State Vocational Schools 2 Depok Yogyakarta. Journal of Critical Reviews, 7(5), 2020.

El-Seedi, H. R., Khalifa, S. A. M., Yosri, N., Khatib, A., Chen, L., Saeed, A., Verpoorte, R. (2019, October 28). Plants mentioned in the Islamic Scriptures (Holy Qur'ân and Ahadith): Traditional uses and medicinal importance in contemporary times. Journal of Ethnopharmacology, Vol. 243, p. 112007. https:// doi.org/10.1016/j.jep.2019.112007

Gerungan, W. A. (1986). Psikologi Sosial. Bandung: Eresco.

H.A. Muhaimin Zen. (1998). Pedoman Pembinaan Tahfidzul Qur'an. Jakarta: Pustaka Al-Husna.

Ibnu Hajar al-Asqalany. (1993). Fathu al-Bary Syarh Shahih BuOiari, Juz 10. Beirut: Dar al-Fikr.

John E. Roberts, Yoonhee Kyung, Brandon Koscinski, Eve Rosenfeld, Hoon-Jin Lee. 2020. Response styles to sad mood and self-esteem as predictors of autobiographical memory: Distinctions between memory specificity and detail, Personality and Individual Differences https:// doi.org/10.1016/j.paid.2020.110142.

M. Suud, F. (2017). Amsal al-Qur'an: Sebuah Kajian dalam Psikologi Pendidikan Islam. FIKROTUNA, 5(1). https:// doi.org/10.32806/jf.v5i1.2952

Muhammad Ali As-shibuni. (282AD). Shofwah at-Tafsir. Jakarta: Dar kutb AlIslamiyah.

Sakho, M. A. (2000). Kiat-Kiat Menghafal Al-Qur'an. Jawa Barat: Badan Koordinasi TQA.

Sudirman, S. A., Suud, F. M., \& Sari, D. P. (2019). Dilatasi memori; leksikon bahasa inggris melalui musik. Psychopolytan: Jurnal Psikologi, 2(2), 96-104. 
Suharsimi Arikunto. (1993). Prosedur Penelitian Suatu Pendekatan Teori Dan Praktek. Jakarta: Rineka Cipta.

Surahmad, W. (2002). Prosedur Penelitian Suatu Pendekatan Praktek. Jakarta: Rineka Cipta.

Sutari Imam Barnadib. (1987). Pengantar Ilmu Pendidikan Sistematis. Yogyakarta: FIP, IKIP.

Sutrisno Hadi. (1990). Metodologi Riset. Yogyakarta: Andi Offset.

Suud, F., \& Subandi, . (2018). Kejujuran dalam perspektif psikologi Islam. Jurnal Psikologi Islam, 4(2), 121-134. Retrieved from http://jpi.apihimpsi.org/index.php/jpi/article/view/44

Suud, F. M. (2017). Amsal al-Qur'an: Sebuah Kajian dalam Psikologi Pendidikan Islam. Fikrotuna, 5(1).

Syachrul, R. M. M. A. K., Bijaksana, M. A., \& Huda, A. F. (2019). Person entity recognition for the Indonesian Qur'an translation with the approach hidden Markov model-viterbi. Procedia Computer Science, 157, 214-220. https:/ / doi.org/10.1016/j.procs.2019.08.160

Syaifuddin Azwar. (2005). Metode Penelitian. Yogyakarta: Pustaka Pelajar.

Syaiful Romadhon, M., Rahmah, A., \& Wirani, Y. (2019). Blended learning system using social media for college student: A case of tahsin education. Procedia Computer Science, 161, 160-167. https://doi.org/10.1016/j.procs.2019.11.111

Winarno Surahman. (1992). Pengantar Penelitian Ilmiah Dasar Metode dan Tehnik. Bandung: Tarsito.

Zuhurudeen, F. M., \& Huang, Y. T. (2016). Effects of statistical learning on the acquisition of grammatical categories through Qur'anic memorization: A natural experiment. Cognition, 148, 79-84.

https://doi.org/10.1016/j.cognition.2015.12.014 